\title{
The Society for Equality in the Hungarian Revolution of 1848
}

Hungary was a feudal monarchy at the beginning of 1848 and was part of the multinational Habsburg Empire. Although Hungarian publicists continually emphasized that the country could look back to nearly a thousand years of statehood and national existence, the foreign relations and the fiscal and military affairs of Hungary were directed almost exclusively from Vienna. Internally the country was governed by the native nobility, which constituted about 5 percent of a population of approximately fifteen million. The nobility exercised its power through the Diet and elective county assemblies. Nobles alone had the right to vote. Until 1844 they alone held public office, and most of them paid no taxes. The immense majority - the peasantry-lived in feudal bondage. The taxes of the serfs maintained the state, and their dues and labor services supported the nobility.

Under the influence of the Europe-wide revolutionary movements in March and April 1848 the Hungarian Diet abolished feudalism through the so-called April Laws. Equality of taxation was introduced, civil liberties were granted to everyone, and a great many peasants were given clear title to their land, which previously had been subject to feudal obligations.

This great social change was carried through the Diet by a group of liberal nobles, among whom Lajos Kossuth, Ferenc Deák, and Count Lajos Batthyány were the most prominent. Besides the social reforms they also succeeded in asserting Hungary's national rights against Vienna. Under Batthyány an independent Hungarian government (including the Ministry of Finance and the Ministry of War) was formed, and the existing ties with Austria were reduced to not much more than a mere personal union. In bringing about these reforms, Kossuth, Deák, and Batthyány had the support of the Diet and of the great majority of the Hungarian nation.

Next to these nobles a group of radical revolutionary intellectuals made the greatest contribution to the Hungarian cause. These men, mostly in their twenties, included the greatest Hungarian poet of the nineteenth century Sándor Petőfi, his close friend and Hungary's most popular novelist Mór Jókai, the well-read historian Pál Vasvári, and the brilliant journalists József Irinyi and Albert Pálffy. There were numerous other writers, poets, journalists, and university students who formed the radical Left in 1848. 
The cultural and revolutionary tradition that emanated from France was the greatest single influence upon these men. Jókai wrote in his memoirs:

We were all Frenchmen. We read only Lamartine, Michelet, Louis Blanc, Sue, Victor Hugo, and Béranger. If we deigned to read an English or German poet, it was Shelley or Heine, disowned by their own countrymen and English and German with respect only to their languages; in spirit, they were French. In Petoofi's case, the adoration of the French was a real cult. His room was filled with valuable engravings of the men of the ' 89 revolution which he had had brought from Paris. They represented Robespierre, St. Just, Marat, and Madame Roland. ${ }^{1}$

On the initiative of these radical intellectuals a revolutionary demonstration took place in Budapest on March 15, and it resulted in the immediate abolition of censorship and the establishment of the Committee of Public Safety, which took over the administration of the city for a month. The committee competed with the Diet and the Batthyány government for national leadership. As a result of this competition and the revolutionary situation, the Diet granted more rights to the people than the deputies originally had intended, and the court in Vienna, fearing anarchy and republic in Budapest, agreed to go along with the genuinely moderate Batthyány in order to avert the greater danger represented by the radicals. ${ }^{2}$

The radical intellectuals' influence was reduced after the Batthyány government established itself in Budapest and took over the administration of the country in mid-April. Only a few radicals succeeded in getting elected to the first representative Assembly, where the government gained an overwhelming majority. ${ }^{3}$ The government of Count Batthyány could be best described as liberal in the early nineteenth-century meaning of the term. It stood for civil liberties for everyone but granted suffrage only on the basis of property qualifications-including about one half of the adult male population of the country. ${ }^{4}$ It believed in freedom of the press but allowed the establishment of only news-

1. Pál Pándi, ed., A magyar irodalom története 1772-töl 1849-ig [History of Hungarian Literature from 1772 to 1849] (Budapest, 1965), p. 766.

2. For the role of the Committee of Public Safety see the March and April issues of the newspaper of the radicals, Marczius Tizenötödike [March Fifteenth], and two important contemporary pamphlets: Akos Birányi, Pesti forradalom (Martius 15-19) [Revolution in Pest (March 15-19)] (Pest, 1848), and István Kléh, $A$ pesti forradalom története 1848-ban [History of the Revolution in Pest in 1848] (Pest, 1848).

3. It is characteristic that even Petöfi, who was a nationally known poet and the chief organizer of the March 15 demonstration, failed at the elections. Sándor Petöf, Ósszes prózai mĩvei és levelezése [Complete Prose and Correspondence] (Budapest, 1960), pp. 429-43.

4. Mihály Horváth, Huszonöt év Magyarország történelméböl 1823-tól 1848-ig [Twenty-five Years of Hungary's History from 1823 to 1848], 3 vols. (Pest, 1868-86), 3:399. 
papers which could make a substantial down payment as "security" against possible libel. Freedom of religion was interpreted as applying to all Christian denominations but not to the Jews. ${ }^{5}$ Above all the Batthyány government wanted to preserve legality. It stood on the basis of the April Laws, sanctioned by the king, guaranteeing the abolition of feudalism as well as Hungary's privileged position within the Habsburg Monarchy.

Opposition to the moderate government became more vocal after the first representative Assembly met in early July. Since the radical intellectuals around Petófi did not gain seats in the parliament, the leadership passed from them to a group of deputies holding similar views. They numbered approximately fifty out of about three hundred representatives attending the regular sessions of the Assembly. ${ }^{6}$ This group of deputies formed the second most important group of radicals in Hungary.

These parliamentary radicals were very different in social background from the young radical intellectuals around Petöf. For the most part they were estate-owning nobles. ${ }^{7}$ They came from the patriotic lesser nobility and had belonged to the liberal opposition before March 1848. Many of them were not newcomers to the political arena, since they had held elective offices before, either as deputies to the Diet or as officials in the county administrative system.

Among them, László Madarász was one of the most conspicuous figures. At the last meeting of the estates, he had been the first to address the deputies simply as "gentlemen" and not "honorable estates and orders." His brother József also was in this group, along with Mór Perczel, a well-to-do gentry estate-owner who participated in the revolution in Budapest during the March Days, and was now a deputy as well as a high-ranking official in the Ministry of the Interior. Several in this group of parliamentary radicals were from the high aristocracy.

These politicians ran on individual radical platforms. A typical radical program submitted to the electorate urged universal suffrage and called for the abolition of the Upper House as contrary to democratic principles ; it demanded expropriation of the vast church estates and a state-financed school system. The program opposed corporal punishment, including capital punishment, and favored reducing the term of military service from six to four years. ${ }^{8}$

Together with Petőf's circle of friends, these deputies formed a radical club in Budapest in mid-July 1848, calling it the Society for Equality. This

5. Dezső Márkus, ecl., 1836-1868 évi törvényczikkck [Law Articles of 1836-1868] (Budapest, 1896), pp. 238-44.

6. This number was given by one of the radical deputies, Mihály Táncsics, in a contemporary newspaper article (Munkások Ujsága, July 16, 1848, p. 244). The parliamentary diaries show thirty-six opposition votes to the government initially.

7. Mihály Táncsics, Eletpályám [The Course of My Life] (Budapest, 1949), p. 253.

8. József Madarász, Emlékirataim [My Memoirs] (Budapest, 1883), pp. 122-24. 
club rapidly developed into the most important radical organization in the Hungarian revolution. In its program the Society put forth the following principles:

We have united to achieve real, unconditional freedom of the press, not dependent upon any preliminary security deposits.

We have united to achieve civil rights unrestricted by any property qualifications.

We have united to lay siege to and destroy prejudices which maintain class barriers between citizens.

We have united to bring about the disappearance of hostility based on the existence of different languages; we welcome into our association any citizen irrespective of language, for the cause of freedom is common and can be achieved only through mutual efforts. ${ }^{9}$

This statement of purpose went far toward clarifying the ideology of radicalism in Hungary in 1848. It went further toward stressing equality in addition to liberty than the Batthyány government's aim to create a liberal state, founded on civil liberties and responsible parliamentary government. The radicals desired universal suffrage and the right of all to participate in decision-making, regardless of wealth or property. They perceived that the introduction of universal suffrage alone would not bring about democracy. They recognized the need to combat and remove class prejudices, which were to remain one of the major ills of Hungarian society until very recently. ${ }^{10}$ Such views place the Society of Equality in the mainstream of European radical democratic movements.

Following the announcement of its program, the Society for Equality met weekly under the chairmanship of László Madarász. Its deliberations and resolutions were publicized in the Society's newspaper, Népelem Radical Lap.11 The first concern of the members was real freedom of the press. A petition to the Assembly called for abolishing the requirement of security deposits. The petitioners argued that no other profession had to meet such a requirement,

9. Quoted by Sándor Fekete, $A$ márciusi fiatalok [The Youth of March] (Budapest, 1950), pp. 114-15.

10. The name "Society for Equality" reminds one of Babeuf's organization in France in the 1790s. It is almost certain that the name of the Hungarian radical club was borrowed from the "Society of Equals." However, to the Hungarian radicals equality meant only equality of rights. They did not even lean toward equality of means, which was the most important feature of Babeuf's program.

11. Népelem Radical Lap [Radical Democrat] (hereafter cited as $N R L$ ), the official organ of the Society, gave detailed accounts of each meeting and printed the texts of all resolutions. It is the main source of information on the Society's activities, which, so far as is known, have not been examined by any historian or commented upon, apart from passing remarks. 
that the existing press laws unjustly supposed journalists and writers to be morally suspect, and that men of letters were prevented from using their talents freely and were condemned to a role of "mercenaries of big capitalists." 12 The Assembly did not act on the demand, however, and the press laws remained unchanged during the entire revolutionary period.

The Society was more successful, if indirectly, with another issue which appeared on its August 6 agenda. After a lengthy discussion, a resolution was adopted which demanded complete emancipation of the Jews in the name of natural law, justice, and equality:

"Representatives, it is your duty to give equal rights to the sons of the same fatherland. It is your duty to put an end to the prejudice of the masses and to bring about justice with the help of legislative power... . A nation which tolerates slaves among its ranks is not worthy of the greatest treasure on earth: Liberty. Show that you are worthy of liberty."13

This resolution supported a bill proposing complete emancipation of the Jews submitted a few days earlier by a radical noble deputy, Ödön Kállay. ${ }^{14}$ On July 28,1849 , in one of its last acts, the Assembly granted full and equal rights of citizenship to "every inhabitant of the Mosaic faith who was born in or was legally settled within the boundaries of Hungary."15

Members of the Society also achieved a partial victory in regard to the abolition of certain feudal remnants not covered by the April Laws. Radical deputies submitted a number of bills to the Assembly in July and August to eliminate the last vestiges of feudalism. One of the active participants of the March Days, Pál Nyári, proposed that all dues to noble proprietors in kind and in labor services be commuted into money payments. László Madarász recommended the abolition of noble monopolies of hunting and fishing, together with the exclusive rights of the nobles to maintain mills, butcher shops, and taverns. The radical journalist Mihály Táncsics submitted a bill to abolish

12. NRL, Aug. 2, 1848, pp. 111-12.

13. $N R L$, Aug. 8,1848, p. 130 (text of the resolution). For a further description of the discussion on Jewish emancipation see $N R L$, Aug. 10, 1848, p. 139.

14. Kállay was not formally a member of the Society, but he cooperated with them on many issues. Once the question of Jewish emancipation was raised and was given emphatic support by the Society, the deputies in the Assembly agreed that it was desirable, because it was the logical consequence of the principle of equality. However, they wanted to discuss Jewish emancipation together with a bill defining Hungarian nationality and establishing immigration and naturalization procedures. See János Beér, ed., Az 1848/49 évi népképviseleti országgyülés [The 1848/49 Popular Representative Assembly] (Budapest, 1954), pp. 869-70. This work includes the text of the minutes of every parliamentary session and the rules, proposed bills, laws, and resolutions passed by the Assembly in 1848-49. Together with the parliamentary diaries edited by Pap (see note 17) it provides a complete account of all parliamentary activities.

15. Ibid., p. 873. The law eventually passed by the Assembly was submitted by the minister of the interior. The text followed closely Kállay's original proposal. 
the tax in kind on vineyards which the peasants considered one of their most serious grievances. ${ }^{16}$ In mid-September the bill on the vineyard tax was brought up by Kossuth and passed. ${ }^{17}$

Although the Society for Equality originally was concerned with internal social reforms, it was forced to turn its attention to the problems of Hungary's relationship with Austria and the danger of counterrevolution which had been developing, and which became most pressing during the late summer. In the spring of 1848 all the major nationalities within Hungary (Rumanians, Slovaks, Croats, Serbs, etc.) demanded autonomy and recognition of their national existence. The Croats, politically the most mature, who had had an autonomous province within Hungary for seven hundred years, wished even to separate from Hungary and to be directly under the Austrian imperial crown. Batthyány's government refused to accede to the demands of the non-Magyar nationalities, and measures were taken against several of their representatives. Conditions deteriorated rapidly, and in early summer the country was faced with civil war. Excited Serbian peasants in the south and Rumanian peasants in Transylvania attacked their Magyar neighbors and committed atrocities. Although the Serbian and Rumanian uprisings caused considerable loss of life and property, the main danger came from Croatia, where the banus, Baron Joseph Jellačić, refused to accept the authority of the Budapest government and took a threatening position toward Hungary.

The conflict between Magyars and non-Magyars in Hungary was one of the most unfortunate aspects of the 1848 revolution. Behind the nationalities' demands one can detect the same desire for freedom that motivated the Magyars themselves. It was understandable that the nationalities looked to the Habsburgs for support after they had been rebuffed in Budapest. However, by siding with the Habsburgs they appeared to the Magyars to be enemies of Hungary's freedom.

Recognizing that Hungary's future depended on her military potential, the Assembly decided in July, at Kossuth's request, to establish a Hungarian army of two hundred thousand. Later, however, the government attempted to gain the Assembly's approval to enlist the new recruits in existing regiments of the Imperial-Royal Army. ${ }^{18}$ Since the army was led by officers faithful to the dynasty alone, the value of the new military force for the Hungarian cause would have been highly questionable.

Although eventually most of the new recruits were organized into new

16. Ibid., pp. $636-40$.

17. Ibid., p. 685. See also Dénes Pap, ed., A magyar nemzetgyïlés Pesten 1848-ban [The Hungarian National Assembly in Pest in 1848], 2 vols. (Budapest, 1881), 2:222. This work contains all the speeches and proceedings but not the resolutions or minutes. 18. Beér, As 1848/49 évi népképviseleti országgyülés, pp. 561-62 (text of proposed army bill). 
regiments under Hungarian command, flags, and insignia, the question of army organization led to the most heated denunciation of the government by the radical deputies. The radicals were able to attract 117 votes in opposition, while 226 deputies supported the government's new compromise bill. ${ }^{18}$ During the debate on army organization it became obvious that Kossuth, although a member of the cabinet, did not agree with the government's original proposal and that his stand was quite close to that of the radicals. Thus the possibility of an alliance between Kossuth and the radical opposition developed.

At the Society's August 13 meeting, a hitherto unknown member, Öttevényi, suggested that the Society be expanded by establishing member societies in the major provincial cities. These provincial member organizations would keep in contact with the Society in Budapest and with each other, and could bring strong pressure to bear on the Assembly. This would-be Jacobin also recommended the holding of political banquets. Although a number of journalists spoke in favor of Öttevényi's proposals, László Madarász argued that the Society lacked the financial means to accomplish this, though he declared that those who wanted to try should go ahead. ${ }^{20}$

The Assembly's passage of the army organization bill marked a definite change of attitude of the Society. It seems that rather than exert continued pressure on the Assembly and government, the membership began to contemplate the overthrow of legitimate authority at the August 15 meeting of the Society. The pamphleteer Biranyi spoke to the audience:

Let us not forget that modest associations often develop strength sufficient to overthrow state power. I do not wish to recommend to the Society that it take violent steps for the overthrow of the government, because that would be illegal, and illegal actions are sanctified only by the product of rapidly moving events, by revolution. I only call the attention of the Society to the power which lies hidden in it and which it has to develop. . . . It is the duty of the Society to develop this power, especially at a time when the fatherland is in danger and the government has proved itself incapable of saving it [the reference was to the government's failure to control the Serbian uprising], and the Assembly is also proving itself to be incapable.

In addition, Birányi wanted to organize a public meeting to publicize the Society's patriotic intentions and to gain further strength from the audience..21 Madarász agreed to the idea and wanted to organize a "magnificent" meeting of the Society with the participation of the full membership. This meeting should be followed by a "magnificent" political banquet attended by all mem-

19. Pap, A magyar nemzetgyülés Pesten, 1:387-439, 2:1-40.

20. NRL, Aug. 18, 1848, p. 162.

21. $N R L$, Aug. 21,1848 , pp. 174-75. 
bers including those from the provinces. During an extraordinary meeting on August 23, the Society set September 8 as the date for the banquet. The date was well chosen; it would be a market day, with many people from the countryside in Budapest. Thus, participation in the Society's activities by the public was made possible.

Meanwhile, at the Society's meetings, denunciations of the government became intensified. Vasvári believed that the Assembly had set itself against the nation by passing the army reorganization bill, and felt that the Society should mobilize public opinion against the Assembly to prevent implementation of the bill. ${ }^{22}$ Another radical intellectual denounced as "internal enemies" all those who did not believe Hungary capable of organizing her military forces independently, and warned that internal enemies were more dangerous than external ones. ${ }^{23}$ The reference to internal enemies was not an isolated phenomenon. Petőfi wrote that now was the time for the nation to rise and strike out at its enemies with the force of lightning:

Where is the enemy, you ask? Don't ask.

$\mathrm{He}$ is everywhere you look.

And, the greatest and most dangerous is he

Who, as a brother, clings to our breasts.

The greatest enemy is among us,

Villainous traitorous brothers!

One of them destroys hundreds,

Like a drop of poison in a glass of wine.

The death sentence to them!

Even if the executioner must strike a

hundred thousand blows,

Even if the blood which flows

Would flood through the windows

of the houses from the streets. ${ }^{24}$

The metaphor of the last verse smacks of wild romanticism. Petőfi certainly did not want a blood bath to eliminate Hungary's internal enemies. But he was willing to get rid of the enemies through violent means, if necessary. In a personal letter to a friend written at this time, Petőfi said: "I believe that we are on the eve of a great revolution, and you know that I do not have false suspicions. Then our first task will be to erect an immense gallows and [hang] nine people on it." ${ }^{25}$ Clearly this was a reference to the nine cabinet members.

22. NRL, Aug. 29, 1848, p. 199.

23. $N R L$, Aug. 24, 1848, p. 183.

24. Sándor Petöfi, Osszes költeményei [Complete Poetry], 2 vols. (Budapest, 1954), 2:448-50.

25. Petőfi, Összes prózai müvei, pp. 463-64 (letter dated Aug. 16, 1848). 
At the same time Népelem Radical Lap indicated that dissatisfaction with the government had increased. During late August and early September the political atmosphere was becoming tense. A conservative deputy wrote of how the streets and public places were filled with officers of the newly formed national defense units speaking angrily against the Palatine Archduke Stephen and reactionary ministers and swearing that they would rid the capital of such men in a few days. ${ }^{26}$ Simultaneously the newspaper of the radical intelligentsia, Marczius Tizenötödike, described itself for the first time as the "journal of revolution and barricades."27

The importance of the planned banquet is indicated by contemporary private letters. On August 25 a young man, probably a member of the Society, exhorted a friend in the provinces to "come up for the banquet" and to follow the news in Népelem Radical Lap about the Society, because "it has a great future." ${ }^{28}$ Meanwhile, the adjutant of Archduke Stephen, Count Albert Zichy, a major in the imperial army, wrote to a fellow officer in Italy that things in Budapest could not continue as they were, and that it was an open secret that the radicals would attempt to force the resignations of all the ministers with the exceptions of Kossuth and Szemere, by the means of a banquet at which fifteen thousand peasants would participate. ${ }^{29}$

The fears of the aristocratic army officer in the palatine's entourage were reiterated by a Transylvanian deputy, Károly Topler. On September 4, in a letter to a friend, Topler described Budapest as living through scenes resembling the first years of the French Revolution. ${ }^{80} \mathrm{He}$ declared that although there was as yet no bloodshed, there were many who wanted to bring it about in order to assume power. He said that bad news arrived daily from the Serbian front and about the preparations of Jellačić, and created great excitement in the capital. Madarász and his followers were taking advantage of the reverses and were blaming the government for them, wrote Topler, in order to "incite the people to the highest degree. Then they will hold their state-wide banquet which is planned for September $8 . \ldots$ On that occasion, it is their purpose to overthrow the government through a

26. Lajos Kovács, "A szeptemberi napok 1848-ban" [The September Days of 1848], Budapesti Szemle, 35 (1883): 264. The palatine mentioned by Kovács was Archduke Stephen, royal plenipotentiary in Hungary.

27. Marczius Tizenötödike, Sept. 1, 1848, p. 585.

28. Eszter V. Waldapfel, ed., A forradalom és szabadságharc levelestára [Collection of Letters Concerning the Revolution and War of Independence], 4 vols. (Budapest, 1950-65), 1:399.

29. Ibid., $1: 407$.

30. Imre Deák, ed., 1848: A szabadsagharc története levelekben, ahogyan a kortársak látták [1848: The History of the War of Independence in Letters, as Seen by the Contemporaries] (Budapest, 1942), pp. 211-13 (collection of private letters and official correspondence of King Ferdinand, the palatine, and other important political figures). 
magnificent popular demonstration. After seizing power, it is their plan to convert everyone to patriotism through Robespierrean terrorism."

In the rest of the letter Topler described a meeting of the Society, held on September 3, at which there was open incitement to rebellion. Vasvári demanded that Hungary follow the example of France and save herself from foreign enemies and royalists through an enlightened dictatorship: "The Cabinet should be set aside and those who think themselves capable should take the government into their own hands. They should guillotine the leaders to save the fatherland!"'31

These accounts make it apparent that in the early days of September the Society for Equality was contemplating decisive action. ${ }^{32}$ The question arises whether the radicals had a serious chance of success. The Society's exact numerical strength is not known, but the ustally well-informed Kossuth estimated the membership at around one thousand, including about thirty deputies. ${ }^{33}$ It was not likely that a thousand men could take over a country of fifteen million against the wishes of the population. However, history provides many examples of small minorities near the center of power who had a decisive influence on the outcome of events, especially when under crisis conditions those in power were unable to provide leadership. In Hungary during late August and early September a situation of this sort seemed to be developing.

The war against the Serbs and the threatening danger from the Croats were not being handled well by the government. In addition, the attitude of the court toward Hungary was uncertain. Batthyány and Deák were in Vienna at this time, trying to persuade the king to sanction the army bill and attempting to obtain assurances of support from the court against Jellacić. Batthyány and Deák, as the king's ministers, were following the legal procedures. It would have meant a great victory for Batthyány's policy if the court would agree to a separate Hungarian army and would make firm commitments against Jellačić. The immediate problems of the country might have been solved peacefully, and the radicals of the Society for Equality

31. An account of the meeting described by Topler also appeared in $N R L$, Sept. 6, 1848, pp. 227-28. In substance it confirms Topler's report.

32. The question of the possibility of a second revolution in September 1848 is one of the least-examined aspects of the 1848 revolution in Hungary. Most Hungarian historians pass over the possibility with a few noncommittal sentences. An important reason may be insufficient knowledge of the newspaper of the Society for Equality. Perhaps those leaders of the Society who survived the revolution purposely did not deal with its activities in their memoirs to any great extent because of a feeling of patriotic piety. Since even the moderate Batthyány was executed by the Austrians after the revolution and became a martyr for freedom, no one may have wished to talk about revolutionary plots against his government after his death.

33. Quoted by Fekete, $A$ márciusi fiatalok, p. 176. Kossuth's estimate is supported by the fact that later the Society wanted to set up a private army of one thousand men. 
would have been rebels without a cause. If the court should refuse to approve the army bill, the cabinet would have been compelled either to resign or to implement the bill without royal approval. Since Batthyány was unlikely to follow the latter course, a cabinet crisis could be expected in which there would be an excellent opportunity for the radicals to attempt a seizure of power.

On September 2 nothing definite was known in Budapest about Batthyány's mission. Kossuth informed the House that Batthyány and Deák were holding crucial negotiations with the king on that very day, and asked for everyone's cooperation in maintaining peace and order. ${ }^{34}$

At the September 3 meeting of the Society a journalist named Kocsis suggested that a proclamation be issued to the nation immediately. From the rather brief description given in Népelem Radical Lap, it was clearly a call to arms that the journalist had in mind. "This proposal was met with many opposing views because circumstances have not matured enough to follow this course of action," the paper reported. "What we have to do, we will do in due course. As long as it is possible, we should use light weapons. There will be a time for the heavy ones also." 35 Following a report of the Society's meeting, it was announced that the Society had decided to postpone the banquet planned for September 8, because public attention was occupied with the problem of saving the country and because many young men were absent from the capital. No new date was set, but the possibility of a banquet was reserved for a later time.

The radicals thus acceded to Kossuth's plea to suspend action until the outcome of Batthyány's mission in Vienna became known. In so doing, they subordinated their interests as a political faction to national interests. They would not give the court an excuse to break off the negotiations with Batthyány or to refuse his demands on the grounds that revolutionary disturbances were going on in Budapest.

The mission of Batthyány and Deák in Vienna ended in failure, since no one would enter into substantial negotiations with them..$^{38}$ Instead, a long memorandum from the Austrian cabinet arrived in Budapest with the approval of King Ferdinand. The memorandum claimed that an independent, responsible cabinet for Hungary that included the Ministries of War, Finance, and Foreign Affairs was incompatible with the unity of the Habsburg Empire. It flatly stated that a "Hungarian Kingdom separate from the Austrian Empire was a political impossibility"; and it demanded the re-establishment

34. Pap, A magyar nemzetgyülés Pesten, 2:148-49.

35. $N R L$, Sept. 6,1848 , p. 228.

36. The very moderate Deák described the futility of the mission in an embittered letter dated September 5. Arpád Károlyi, Németuíjvári gróf Batthyány Lajos elsỏ magyar minisaterelnök föbenjáró pöre [High Treason Trial of Count Lajos Batthyány of Németújvár, the First Hungarian Prime Minister], 2 vols. (Budapest, 1932), 2:9-11. 
of a "common state government."37 This memorandum marks the beginning of the court's attempts to revoke the concessions granted in April. The Habsburgs were now in a stronger position because by September 1848 the revolutionary tide had lost a great deal of momentum all over Europe. In Vienna conditions were much quieter than in the spring. The Prague uprising had been defeated by Prince Windischgrätz. In Italy Field Marshal Radetzky had won a decisive victory at Custozza and had re-established Habsburg rule in Lombardy. It appeared that the emperor no longer felt obligated to fulfill his responsibilities as king of Hungary.

Kossuth spoke bitterly to the Assembly about the intrigues of the court. He predicted that the government would not be able to save the country from the impending dangers, and added, "The nation will be forced to provide itself temporarily with such executive power as will not have to derive its means of procedure from the law, but from the need to protect the fatherland."38 Kossuth's willingness to depart from legality brought him very close to the radicals of the Society for Equality. Still, on Kossuth's suggestion, another attempt was made to come to terms with the court. A delegation of one hundred deputies and forty members of the House of Lords took the steamer to Vienna to request the king's cooperation. When they were turned down, according to the British ambassador in Vienna, "they left Vienna having hoisted the red flag and wearing red cockades and feathers in their hats."39

While the parliamentary delegation was in Vienna the radicals adopted a "wait and see" attitude. József Madarász wrote in Népelem Radical Lap that the radicals did not necessarily want to put new people in the government by force. If the government was willing "to raise the standard of the holy principles of the revolution," Madarász was willing to forget the past and to support the cabinet in a new and decisive course of action. ${ }^{40}$

The Society for Equality did not hold its banquet, but it did call a huge meeting on the eighth of September at which a permanent committee was established to keep watch on the political situation. Among the committee's members were such well-known figures as Petôfi, Vasvári, Jókai, Perczel, the Madarász brothers, and several lesser-known but not less radical journalists. These men were divided into four groups, relieving each other every six hours. The Society announced the formation of its vigilante com-

37. Dénes Pap, ed., Okmánytár Magyarország függetlenségi harczânak történetéhez, 1848-1849 [Collection of Documents on the War of Independence in Hungary, 18481849], 2 vols. (Pest, 1868-69), 1:403-18.

38. Pap, $A$ magyar nemzetgyülés Pesten, 2:157.

39. Viscount Ponsonby to Viscount Palmerston, in Correspondence Relative to the Affairs in Hungary, 1847-9 (London, 1850), p. 82.

40. $N R L$, Sept. 7, 1848, p. 229. 
mittee to the citizens by posters, and called upon them to pass on any information to the committee. In addition, it was decided to form a private "national defense" force of one thousand men divided into ten companies, under the command of Perczel. Among the "captains" of this force were Petőf, Vasvári, and Csernátoni, the associate editor of Marczius Tizenötödike.

The Society apparently had some sort of arsenal of its own, because it promised to provide arms to those not able to arm themselves. The volunteers swore upon their honor as patriots to obey the orders of their superiors and to defend the constitution. Recruitment was to be handled by the vigilante committee. This force, however, was not planned as a permanent body. The Society would keep the one thousand men under arms for only three days, until September $12 .{ }^{41}$ It would be hard to accuse the radicals of conspiring secretly to overthrow the government, since they printed the information outlined above on the front page of their newspaper and on posters. How much of their plans was withheld cannot be determined, because there is no information on the details even in memoirs written several decades after the events. $^{42}$ Only a conservative political opponent, a deputy named Lajos Kovács, accused the party of Marczius Tizenötödike and the Madarász brothers of preparing lists of names of those whom they were planning to "proscribe." 43

Although the Society did not give specific reasons for the formation of a private army, the fact that it was to be maintained from September 10 to 12 provides certain clues. The parliamentary delegation was expected to return from Vienna by then. If it brought a refusal, the cabinet would resign. A new cabinet might be formed, but it was possible that the court would designate a prime minister who could not win the confidence of a majority in the Assembly, thus precipitating a crisis.

By making preparations for a possible coup d'état the Society for Equality provided an alternative to legality, the significance of which cannot be overestimated. From the tone of their newspapers, however, it seems that the radicals wanted to establish revolutionary executive power only if all else failed. In this respect they were in substantial agreement with Kossuth. Since Kossuth was the most popular political figure in the country and was willing to depart from legal means if necessary, it is highly probable that

41. $N R L$, Sept. 10, 1848, pp. 241-42.

42. József Madarász, for instance, wrote in depth about the revolution in his memoirs but did not even mention the formation of the vigilante committee or the planned private army. Rather than giving any information about the Society, he chose to write only about generally known developments that took place in the Assembly during the September days.

43. Kovács, “A szeptemberi napok 1848-ban,” p. 263. 
the radicals wanted to have their private army in readiness to seize power with Kossuth.

Prime Minister Batthyány took steps to maintain his government against all threats, and arranged to have Austrian regiments sent to Budapest. ${ }^{44}$ In addition, the Society was dissolved by the police after the formation of the vigilante committee and the call for a private army were made public.45 The dissolution was not taken seriously, however, and the Society continued to function, holding public meetings and demonstrations and issuing manifestoes. But the ban on the Society for Equality did serve the immediate purpose of preventing the formation of the private army. The "dissolved" Society informed the public on the day after the first call to arms that the organization of any "national defense" force had been forbidden until further notice by the Assembly. József Madarász, who signed the announcement, found it necessary to add that no one should believe any slanderous insinuations about the Society, which only wanted to defend the constitutional rights of Hungary against any aggressor. ${ }^{48}$

As expected, upon the return of the delegation the cabinet resigned immediately, but Batthyány again was asked to form a new cabinet. Kossuth gave his support to Batthyány and convinced the Assembly to do likewise. ${ }^{47}$ Between September 12 and 25 Batthyány made repeated attempts to form a new cabinet. These efforts were unsuccessful because the court would not confirm his appointments, even though he included only moderates whose loyalty to the crown was generally known. Kossuth's name was not among any of the new ministerial combinations.

Meanwhile the situation became further complicated. On September 11 Jellačić attacked Hungary with forty thousand men. Jellačić issued a proclamation to the Hungarians promising them peace, order, and freedom from the tyranny of the Ministry in Budapest. ${ }^{48}$ Since the Hungarian cabinet had agreed to the separation of Croatia from Hungary, ${ }^{49}$ Jellačic's invasion was an attempt to re-establish the old order. The Hungarians chose to fight Jellačić. But the invading army of forty thousand was opposed only by a weak force

44. Károlyi, Németúijári gróf Batthyány, 1:116-17. Kossuth and the radical Irányi protested in the Assembly on September 13 against the presence of these troops in Budapest.

45. Mihály Horváth, Magyarország függetlenségi harczának története 1848 és 1849-ben [History of Hungary's War of Independence in 1848 and 1849], 3 vols. (Pest, 1871-72), $1: 355$.

46. NRL, Sept. 10, 1848, p. 244.

47. Pap, A magyar nemzetgyülés Pesten, 2:180-82, 195-97.

48. M. Hartley, The Man Who Saved Austria: The Life and Times of Baron Jellačic (London, 1912), pp. 214-15. ing).

49. Károlyi, Németújvári gróf Batthyány, 2:628-29 (minutes of the cabinet meet- 
of about five thousand, mostly untrained recruits and National Guard, and Jellačić steadily advanced toward Budapest.

In this emergency situation Kossuth became the leader in rallying resistance to Jellačić. On Kossuth's motion the House ordered the immediate organization of the armed force it had approved in August. All new military units were organized into national defense (honvéd) battalions under Hungarian colors and command. Officers and enlisted men of the imperial army were authorized to join the newly formed battalions at once. Kossuth left the capital to recruit volunteers, and his success as an orator was never greater. After his speeches thousands flocked to join the National Guard and immediately were sent to the front.

The radicals of the Society for Equality also went into action. Their main efforts were directed toward organizing the defense of the country and giving political support to Kossuth. Immediately after the Assembly's vote to set up Hungarian battalions and to allow soldiers and officers to transfer to these battalions from the regular army, Perczel and other radicals went among the enlisted men urging them to join the new units. As a result, Hungarian soldiers left their imperial units in large numbers and joined the newly formed Hungarian battalions. ${ }^{50}$ In addition, several volunteer units were organized in Budapest and named after Hunyadi, Zrinyi, and other popular figures from Hungarian history. Perczel became the leader of one such volunteer unit and was soon to distinguish himself in action. Agitation for the national cause also began among the peasantry. Petőfi, Vasvári, József Madarász, and other members of the Society for Equality all spent some time in the provinces, rousing the peasants to the danger and persuading them to take up arms against the enemy.

On behalf of the Society for Equality, Petőfi wrote a proclamation. $\mathrm{He}$ warned the peasants that they would become beasts of burden again if they welcomed Jellačic. He told them they should stand up and fight in the lifeand-death struggle as befitted a free people. ${ }^{51}$ The Society was active in organizing political support for Kossuth. On September 12 a big public meeting was called in the capital where the speakers with the approval of the audience demanded the appointment of Kossuth as prime minister. ${ }^{52}$ The next day Marczius Tizenötödike stated, "Hungary can be saved only by concentrated dictatorial power, and . . . this power must be given to Kossuth."53 József Madarász wrote in Népelem Radical Lap that he and other deputies in the Assembly wanted more action than Batthyány had been

50. Horváth, Magyarország függetlenségi harczának története, 1:382.

51. Petöf's proclamation appeared in NRL, Sept. 20, 1848, pp. 273-74.

52. NRL, Sept. 15, 1848, p. 258.

53. Marczius Tizenötödike, Sept. 13, 1848, p. 627. 
able to produce, and urged a new government under the "presidency of Kossuth."

The radicals in the Assembly also voiced loud support for Kossuth. When Batthyány announced he had been asked to form a new cabinet, he received cheers from the Right. The deputies on the Left, however, responded with shouts of "Long live Kossuth!"'50 The cheers for Kossuth in the Assembly were echoed by large crowds outside the Assembly building who had been brought there by radical agitators. A conservative deputy wrote about the composition of the demonstrating crowds: "He who looked at the rabble stationed around the Assembly building could not see one single reputable burgher from Pest. They were people collected by Madarász and his comrades." ${ }^{58}$

The cooperation between Kossuth and the radical deputies in the Assembly is particularly well illustrated by their joint efforts to form emergency executive power. While Batthyány was still trying to form a cabinet, Kossuth suggested that a House committee be established to gather confidential military information and make recommendations to the Assembly at large. The committee was elected by the Assembly despite Batthyány's opposition. ${ }^{57}$ József Madarász reports in his memoirs that after Kossuth made his proposal, ten or twelve radical deputies sat down to determine whom they would support for membership on the committee. They quickly agreed on a list headed by Kossuth, and a few hundred ballots were prepared with the names of the radical candidates. What happened is worth quoting from Madarász's memoirs:

On the 16th, during the afternoon session, the printed ballots were put on my desk and everything proceeded as I had predicted. . . . The former opposition [i.e., radicals] used the ballots spread in front of me. Since it was impossible for the members of the former government party not to notice this, they too came over to us in great numbers and, finding our candidates acceptable, voted for them. The audience in the galleries noisily cheered the members of the opposition as they entered the hall. This may have contributed to the victory of the minority ballot. The chief reason for our victory, however, was that the country experienced dangerous moments when the House did not know whether there would be a cabinet or if it would collapse. On such an occasion the greater majority yields to the vigorous minority..$^{58}$

54. NRL, Sept. 13, 1848, p. 257.

55. Pap, A magyar nemzetgyülés Pesten, 2:195.

56. Kovács, "A szeptemberi napok 1848-ban," p. 263.

57. Kossuth's suggestions and Batthyány's response are in Pap, $A$ magyar nemzetgyülés Pesten, 2:242-44. See also the minutes of the Assembly in Beér, Az 1848/49 évi népképriseleti országgyülés, pp. 234, 246.

58. Madarász, Emlékirataim, pp. 169-70. 
Subsequent events changed the nature of this committee from an information-gathering agency to a real executive authority known as the Committee of National Defense. King Ferdinand set aside constitutional procedure and appointed Lieutenant Field Marshal Francis Lamberg as commander in chief of the armed forces in Hungary. Lamberg's mission was to stop bloodshed and to re-establish law and order, as well as harmony with the other parts of the empire. ${ }^{59}$ The Assembly in turn declared Lamberg's appointment null and void. ${ }^{60}$ An excited mob, which "seemed for the most part to be made up of the poorest class in the city," stopped Lamberg on the bridge connecting Buda to Pest and brutally murdered him. ${ }^{61}$ The Assembly disapproved of Lamberg's murder but was ready to face the consequences. The minutes read as follows: "the House instructed the Committee of National Defense, consisting of six members, to assume the burden of responsibility until the return of the Prime Minister and to take charge of the defense of the country as well as the maintenance of peace and order." 62 Later the Assembly placed the government of the country permanently in the hands of the committee: "Citizen and Member of the Assembly Kossuth was named president of the new government and he was charged with the responsibility of fixing the tasks of the other members of the committee." ${ }^{\prime 3}$ The radicals came to power with the Committee of National Defense. Four of the six members belonged to the radical faction of the Assembly, and all six were nominees of the radical minority. This was a tremendous victory for the radicals, even if it did not prove to be a lasting one.

On September 29 Jellačić was defeated a few miles from Budapest, and the immediate danger was averted. Five days later the Assembly added four members of the Upper House to the committee, and later two more former cabinet members joined. ${ }^{64}$ So in a time of extreme national danger the Assembly gave power to the radicals, but once the crisis was over it took it back-or more precisely, forced the radicals to share it with the moderates.

The rest of 1848 and 1849 represents a period of revolutionary war against the Habsburgs in Hungarian history. With the establishment of the Committee of National Defense the significance of the Society for Equality began to diminish. As one member put it in his memoirs, the Society "seldom met and finally it dissolved itself." 65 The reduced role of the radicals was due above all to the exigencies of war and to Kossuth's leadership. Many radical

59. Pap, Okmánytár, 2:78-79.

60. Pap, A magyar nemzetgyillés Pesten, 2:303-10.

61. Marczius Tizenötödike, Sept. 29, 1848, p. 689.

62. Beér, Az 1848/49 évi népképviseleti országgyiilés, p. 255.

63. Ibid., p. 273.

64. Pap, $A$ magyar nentzetgyülés Pesten, 2:344.

65. Táncsics, Eletpályám, p. 265. 
intellectuals believed that the time for arguments was over and that words had to be followed by deeds. Instead of holding meetings, Petőfi, Vasvári, and many others joined the army and were transformed from radical agitators into army officers absent from Budapest, without any chance of exercising influence there. Some of the radical deputies served as representatives on mission. One of them, Perczel, a man of action rather than a parliamentarian, became a general and commanded a division. Others, such as László Madarász, assisted Kossuth with the government.

Kossuth with immense energy and ability undertook to organize Hungarian resistance to the Habsburgs and inspired unprecedented enthusiasm among the people for the national cause. The radicals had little reason to challenge Kossuth. They agreed with his view that the foremost task was to defend the nation against the king's troops and to bring the war to a victory. Without that victory, the radicals' hopes for Hungary could never materialize. Thus, with the start of the war, the radical cause merged with the national cause, and the radicals became the champions of the national cause above all. 